\title{
Pengembangan Sistem Informasi Taman Pendidikan Al Qur'an Menggunakan Framework Java Spring
}

\author{
Yance Sonatha $^{* 1}$, Aldo Erianda ${ }^{2}$, Indri Rahmayuni ${ }^{3}$, Tasrik Rizaldi ${ }^{4}$ \\ 1,2,3,4 Jurusan Teknologi Informasi, Politeknik Negeri Padang \\ e-mail: *11 sonatha.yance@gmail.com, ${ }^{2}$ aldoerianda@gmail.com, ${ }^{3}$ rahmayuni@gmail.com
}

\begin{abstract}
Abstrak
Taman Pendidikan Al Qur'an merupakan sebuah lembaga pendidikan Agama Islam non formal yang bertujuan untuk mengajarkan Al Qur'an sejak usia dini. Salah satunya adalah TPA Al HIjrah yang terletak di Kecamatan Nanggalo Padang, Indonesia. Selama ini proses akademik pada TPA masih menggunakan pendataan sederhana secara manual. Penelitian ini menggunakan metode System Development Life Cycle (SDLC) dan bertujuan untuk menghasilkan sebuah sistem informasi yang dapat mengelola data data dan menyajikan informasi tentang TPA tersebut yang bisa diakses dimana saja. PIECES framework digunakan untuk melakukan analisis kebutuhan sistem, sedangkan dalam perancangannya menggunakan metode UnifiedModellingLanguage. Dalam pengembangan sistem digunakan bahasa pemrograman Java dengan Framework Spring. Sistem yang dihasilkan memiliki 3 jenis hak akses yakni administrator sistem, guru dan santri dan nantinya bisa diakses secara online.
\end{abstract}

Kata kunci-Java, PIECES Framework, SDLC, Spring Framework, Taman Pendidikan AlQur'an(TPA), UML

\begin{abstract}
Al Qur'an Education School (TPA) is a non-formal Islamic educational institutiont hataims to teach them Qur'an from anearlyage. One of themis Al Hijrah TPA whichis located in Nanggalo District, Padang, Indonesia. Sofar, the academic process in TPA still collects data manually. This study used the System Development Life Cycle (SDLC) method and aimed to producean information system that can manage data and present information about the TPA. User scan access it any where and any time. PIECES frame work isused to analyze system requirements, while the Unified Modeling Language (UML) method isused in the design stage. In developing the system, the Java programming language isused with Framework Spring. The resulting system has 3 type soft access rights namely system administrators, teachers and students. The system can later be accessed online.
\end{abstract}

Keywords_Java, PIECES Framework, SDLC, Spring Framework, Taman Pendidikan AlQur'an(TPA), UML

\section{PENDAHULUAN}

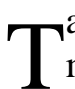
aman Pendidikan Al-Qur'an (TPA) adalah lembaga atau kelompok yang masyarakat yang menyelenggarakan pendidikan non formal jenis keagamaan Islam yang bertujuan untuk memberikan pengajaran membaca Al-Qur' an sejak usia dini, serta memahami dasar-dasar dinul Islam pada anak usia taman kanak-kanak, sekolah dasar dan madrasah ibtidaiyah atau bahkan yang lebih tinggi. TPA dapat dijadikan sebagai pengkaderan santri yang mampu berdiri 
sendiri, bebas dan teguh dalam kepribadiannya, menyebarkan agama, menegakkan kejayaan islam dan umat ditengah-tengah masyarakat. [1]

TPA Al-Hijrah Kecamatan Nanggalo merupakan salah satu TPA yang berada di Kota Padang. Berdasarkan pengakuan pengurus TPA Al-Hijrah, saat ini pengelolaan data santri baik itu administrasi, keuangan, dan kegiatan masih menggunakan sistem manual. Dampak yang ditimbulkan dari sistem manual ini sering terjadi kesalahan penginputan data yang menyebabkan kevalidan data dipertanyakan. Tentu hal ini sangat berisiko dan memungkinkan terjadi kehilangan data yang tidak dikehendaki.

Untuk mengatasi permasalahan ini, sistem informasi terpadu dapat digunakan untuk mengelola kebutuhan akademik, administrasi, keuangan, dan kegiatan yang ada pada TPA tersebut. Dengan menggabungkan keilmuan teknologi informasi pada TPA tersebut akan tercipta produk teknologi informasi dalam aspek keagaaman.

Dari hasil kajian pustaka, diperoleh beberapa penelitian terdahulu yang menjadikan TPA sebagai objek penelitian, diantaranya pembuatan web pada TPA An Nida Jember [1], pembuatan e-learning di TPA Al Fadhillah di Sukohardjo [2] dan pembuatan sistem informasi akademis berbasis web di Badan Koordinasi TPA Serang [3]. Ketiga penelitian tersebut memiliki kesamaan dalam pemanfaatan web untuk menyajikan informasi tetapi menggunakan teknologi yang berbeda-beda.

\section{A. Sistem Informasi}

Sistem informasi memiliki tiga definisi berikut ini : [4]

1 Sistem informasi adalah sistem yang diciptakan oleh manusia. Sistem informasi memiliki komponen-komponen di dalam organisasi yang memiliki tujuan yaitu menyajikan informasi.

2 Sistem informasi adalah sekumpulan prosedur organisasi yang pada saat dilaksanakan akan memberikan umpan balik berupa informasi yang bermanfaat untuk pengambilan keputusan dan atau untuk memanajemen sebuah organisasi.

3 Sistem informasi adalah sebuah sistem didalam suatu organisasi yang menggabungkan kebutuhan pengelolahan transaksi, mendukung operasi, bersifat manajerial, dan kegiatan strategi dari suatu organisasi serta menyediakan laporan yang dapat digunakan oleh berbagai pihak yang membutuhkan.

\section{B. PIECES Framework}

PIECES Framework merupakan sebuah framework yang berisi kategori-kategori pengklasifikasian masalah dan membuat pemecahan dari masalah tersebut. Klasifikasi tersebut dibagi menjadi 6 kategori sebagai berikut: [5]

Tabel 1. Kategori PIECES Framework

\begin{tabular}{llll}
\hline Initial & \multicolumn{4}{c}{ Deskripsi } \\
\hline $\mathrm{P}$ & $\begin{array}{l}\text { Kebutuhan untuk } \\
\text { performance }\end{array}$ \\
$\mathrm{I}$ & $\begin{array}{l}\text { Kebutuhan untuk memperbaiki dan } \\
\text { informasi dan data }\end{array}$ & meningkatkan \\
$\mathrm{E}$ & $\begin{array}{l}\text { Kebutuhan untuk memperbaiki dan } \\
\text { ekonomi, biaya kontrol dan meningkatkan keuntungan }\end{array}$ \\
$\mathrm{C}$ & $\begin{array}{l}\text { Kebutuhan untuk memperbaiki dan meningkatkan kontrol } \\
\text { dan keamanan }\end{array}$ \\
$\mathrm{E}$ & $\begin{array}{l}\text { Kebutuhan untuk memperbaiki dan meningkatkan efisiensi } \\
\text { dari sumber daya dan proses }\end{array}$ \\
$\mathrm{S}$ & Kebutuhan untuk memperbaiki dan meningkatkan layanan \\
\hline
\end{tabular}

Yance et., al (Pengembangan Sistem Informasi Taman Pendidikan Al Qur'an Menggunakan Framework Java Spring) 
kepada pelanggan, supplier, pekerja dan sebagainya

\section{Spring Framework}

Framework spring adalah framework open source berbasis java yang menyediakan infrastruktur yang komprehensif dalam mengembangkan aplikasi java dengan mudah dan cepat. Spring pertama kali ditulis dan dirilis oleh Rod Johnson dengan lisensi Apache 2.0 pada bulan Juni 2003. Spring akan membantu programmer dalam pengembangan aplikasi dengan build yang sederhana, portable, cepat dan sistem berbasis JVM yang fleksibel. Spring dapat digunakan untuk melakukan pengaturan deklarasi manajemen transaksi, remote access dengan menggunakan RMI atau layanan web lainnya, fasilitas mailing, dan beragam opsi untuk pengaturan data ke database. Spring juga memungkinkan kita menggunakan hanya modulmodul tertentu sehingga kita tidak perlu menggunakan semua modul spring dalam aplikasi apabila tidak diperlukan. [6]

Spring Framework menggunakan teknik pemrograman yang sederhana, model pemrograman dengan Spring cukup mudah, namun rapi. Hal Ini memudahkan bagi para developer pemula untuk mempelajarinya. Jika mempelajari Spring, para developer berevolusi menjadi developer yang lebih baik. Hal ini karena framework Spring mendorong untuk membuat kode program yang modular dan independen. Hasilnya, kode program yang dibuat akan lebih rapi, mudah dites, dan terstruktur dengan baik.

\section{Spring $M V C$}

Spring MVC merupakan kerangka kerja open source berbasis java yang menyediakan infrastruktur untuk mengembangkan aplikasi. Spring pertama kali dirilis oleh Rod Johnson dengan lisensi Apache 2.0 pada tahun 2003. Spring termasuk portable karena aplikasi yang dikembangkan dapat berjalan pada JVM manapun.

Fitur yang disediakan oleh Spring $M V C$ antara lain adalah konsep MVC (Model View Controller). Konsep MVC banyak digunakan dibahasa pemrograman java sebagai desain pattern. Konsep MVC digunakan untuk membuat aplikasi java yang memiliki tampilan (View), model yang berfungsi sebagai objek penghubung antara apllikasi dengan database dan controllerdigunakan untuk mengatur requestyang ada dalam aplikasi tersebut. Konsep MVC ini dapat membangun web menjadi lebih terstruktur. [7]

\section{METODE PENELITIAN}

Dalam penelitian ini, digunakan metode Software Development Life Cycle(SDLC). SDLC merupakan tahapan-tahapan yang dilakukan untuk membangun sebuah sistem informasi melalui 10 tahapan yakni Initiation, Software Concept Development, Planning, Requirement Analysis, Design, Development, Integrationand Testing, Implementation, Operationand Maintenance dan Disposition. [8]-[9] Untuk penelitian kali ini digunakan 5 dari 10 tahapan SDLC sebagai berikut

1. Analisis Kebutuhan (RequirementsAnalysis)

Analisis kebutuhan merupakan proses menganalisis dan mengembangkan kebutuhan pengguna sistem informasi berbasi web dan membuat dokumen kebutuhan fungsional. Pada tahap ini dilakukan pengumpulan data melalui sebuah penelitian langsung ke Masjid Al-Hijrah Kecamatan Nanggalo, Kota Padang.

2. Desain (Design)

Desain adalah proses yang berfokus pada desain pembuatan sistem yang berbasis web dengan proses pengkodean.

3. Pengembangan (Development) 
Pengembangan merupakan tahapan mengkonversikandesan ke sistem informasi yang lengkap seperti: menyiapkan berkas dan prosedur kasus, pengujian sistem, membuat database, membuat kode program, dan lain-lain.

4. Integrasi dan Pengujian (Integrationand Testing)

Integrasi dan pengujian merupakan tahapan untuk mengetahui sistem informasi yang dibuat apakah sudah sesuai dengan spesifikasi dokumen fungsional atau tidak. Hal ini dilakukan untuk memastikan bahwa aplikasi yang dibuat sesuai dengan desain dan tahapan pembuatan aplikasi.

5. Implementasi (Implementation)

Setelah melakukan pembuatan sistem tahap selanjutnya yaitu implementasi sistem. Setelah melakukan analisa kebutuhan user, desain, pengkodean maka sistem yang sudah selesai dibuat akan digunakan oleh user. Selain itu hal ini juga bertujuan untuk menemukan kesalahan-kesalahan dan memastikan bahwa input yang dibatasi akan memberikan hasil aktual yang sesuai dengan hasil yang diharapkan setelah sistem ini selesai.

\section{HASIL DAN PEMBAHASAN}

\section{A. Requirements Analysis}

Masalah yang dihadapi sekarang ini adalah belum adanya sebuah sistem yang bisa diakses dimana saja yang dapat menyajikan informasi mengenai proses akademik di TPA Al HIjrah. Kesulitan tersebut tergambar dalam PIECES framework berikut ini: [10]

a. Performances

Dalam pengelolaan data administrasi dan kegiatan TPA di Masjid Al-Hijrah masih belum memiliki sistem yang terkomputerisasi. Sistem yang ada saat ini hanya mengelola data seputar kegiatan TPA dengan pengarsipan yang masih manual yang sangat rentan menimbulkan kehilangan data.

b. Informations

Informasi yang dihasilkan saat ini untuk mengetahui jadwal kegiatan TPA dilakukan dengan menampilkan informasi langsung di papan pengumuman. Bahkan, informasi mengenai presensi santri belum ada pelaporannya.

c. Economics

Proses yang dilakukan saat ini dalam mengelola data administrasi dan kegiatan TPA tentu banyak melibatkan penggunaan kertas sebagai media yang digunakan dalam setiap proses yang ada. Seperti dokumen untuk pengarsipan data santri, pengarsipan pembayaran SPP dan proses penilaian. Sehingga, biaya yang digunakan pun untuk kebutuhan pencetakan dokumen relatif cukup besar.

d. Controls

Pengelolaan data administrasi santri dan kegiatan TPA masih dilakukan secara manual dalam pembukuan atau pun proses pelaporan dan masih belum tersimpan ke dalam database. Data yang ada bisa saja hilang bahkan tercecer. Kendali tenaga administrasi dalam mengamankan data belum dapat dikatakan sepenuhnya aman. Apabila sudah tersimpan di database maka pihak administrasi sendiri akan mudah melakukan pencarian yang sekarang atau sebelumnya dimana telah tersimpan pada database. Bahkan, kehilangan data yang terjadi dapat diminimalisir.

e. Eficiency

Pengelolaan data administrasi santri dan kegiatan TPA yang belum terkomputerisasi seperti yang telah dijelaskan sebelumnya tentu akan kurang efisien dalam mengelola data administrasi santri dan kegiatan TPA. Proses pencarian data yang diperlukan dilakukan secara manual berdasarkan dokumen-dokumen yang ada. Sehinggga, 
pendataan yang dilakukan akan membutuhkan waktu dan tenaga yang banyak dalam proses pengelolaannya.

f. Services

Pelayanan informasi yang diberikan pihak TPA dapat dikategorikan baik. Namun, keterbatasan proses tatap muka pihak TPA dengan santri ataupun orang tua terkadang tidak sampainya informasi seputar kegiatan dan proses pembelajaran santri di TPA. Hal ini dikarenakan masih menggunakan cara pencatatan secara tertulis. Sehingga, pelayanan informasi yang seharusnya baik menjadi kurang tersampaikan karena proses yang masih manual.

B. Design

Perancangan Sistem Informasi TPA Al Hijrah menggunakan UML. Sistem memiliki 3 level akses (aktor) yakni administrator sistem, santri dan guru. Rancangan interaksi antara sistem dengan aktor dapat dilihat pada use case diagram sesuai dengan gambar 1 berikut.

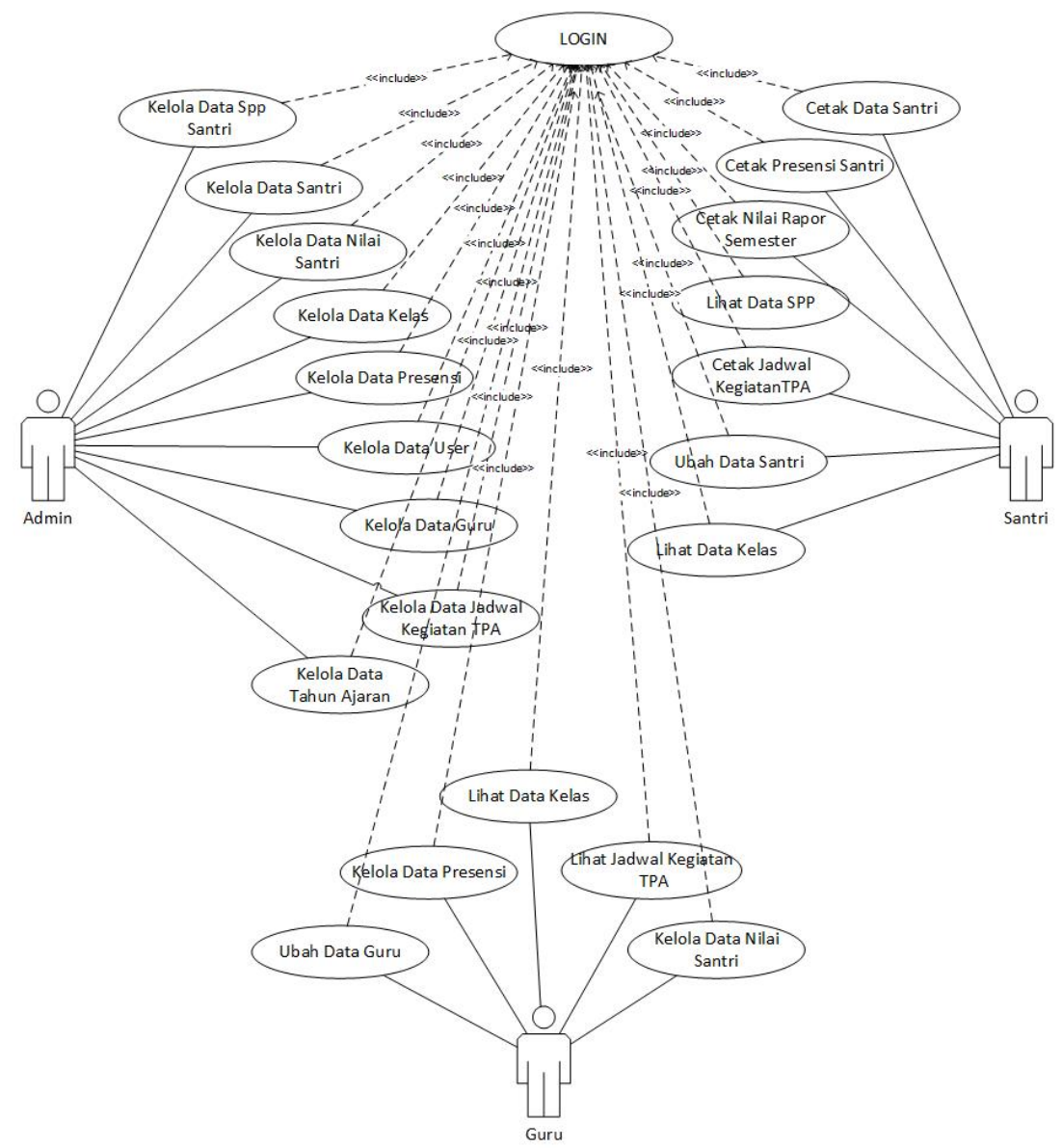

Gambar 1. Use Case Diagram

\section{Development}

Sistem dikembangkan berdasarkan rancangan dengan menggunakan perangkat lunak yang spesifikasinya sebagai berikut:

$\begin{array}{lll}\text { - } & \text { Sistem Operasi } & \text { : Windows } 10 \text { Home Single Language } 64 \text { bit } \\ \text { - } & \text { DBMS } & \text { : MySQL } \\ \text { - } & \text { Tools } & \text { : XAMPP 3.2.2 }\end{array}$

Yance et., al (Pengembangan Sistem Informasi Taman Pendidikan Al Qur'an Menggunakan Framework Java Spring) 


$\begin{array}{ll}\text { - } & \text { Server } \\ \text { - } & \text { Alat Bantu Perancangan } \\ \text { - } & \text { Text Editor } \\ \text { - } & \text { Bahasa Pemrograman }\end{array}$

: Glassfish

: Balsamic Mockups

: Eclipse Luna

: Java/Framework Spring

\section{Integrationand Testing}

Tahap integrasi dan pengujian dilakukan dengan mengakses sistem menggunakan 3 akses yang berbeda yakni sebagai administrator, santri dan guru. Sistem menampilkan menu yang berbeda sesuai dengan rancangan sebelumnya. Gambar 2 memperlihatkan tampilan menu yang bisa diakses oleh administrator sistem yakni menu data santri, guru, kelas, jadwal kegiatan TPA, tahun ajaran, tingkatan, data user, presensi kelas dan nilai rapor santri.

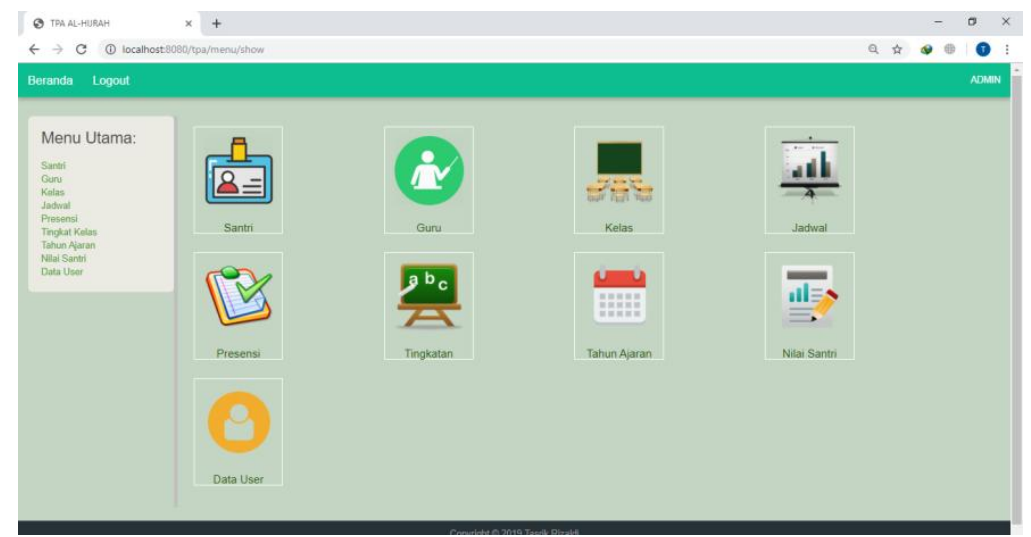

Gambar 2. Tampilan Menu Utama Administrator

Sementara gambar 3 berikut memperlihatkan menu utama dimana santri bisa mengubah data pribadi, mencetak presensi masing-masing, mencetak rapor nilai semester dan mencetak jadwal kegiatan

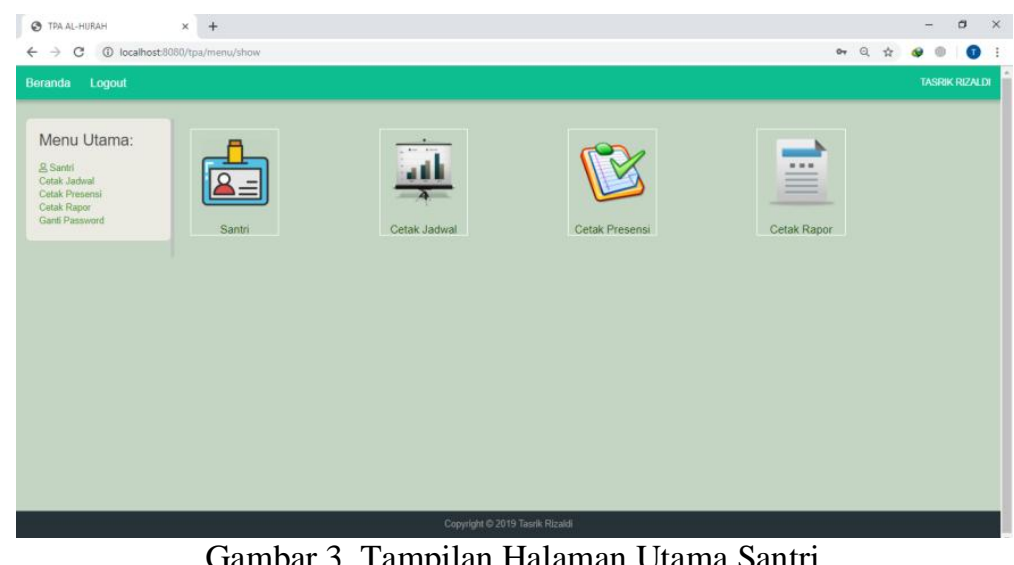

Gambar 3. Tampilan Halaman Utama Santri

Pada halaman utama dengan user guru pada Gambar 4 berikut terdapat 5 menu utama yang dimana guru bisa mengubah data pribadi, mengelola data presensi kelas, mengelola data nilai santri masing-masing kelas, dan melihat serta mencetak jadwal kegiatan TPA. 


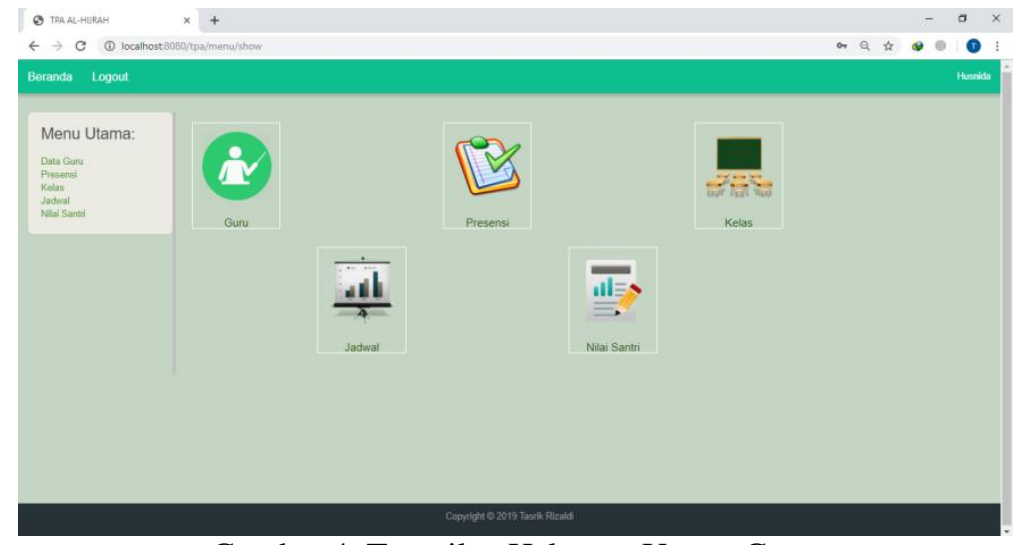

Gambar 4. Tampilan Halaman Utama Guru

\section{E. Implementation}

Tahapan selanjutnya adalah implementasisistemmenggunakan data yang sebenarnya. Gambar 5 berikutinimemperlihatkantampilanrekapitulasi data santri yang ada pada menu administrator.

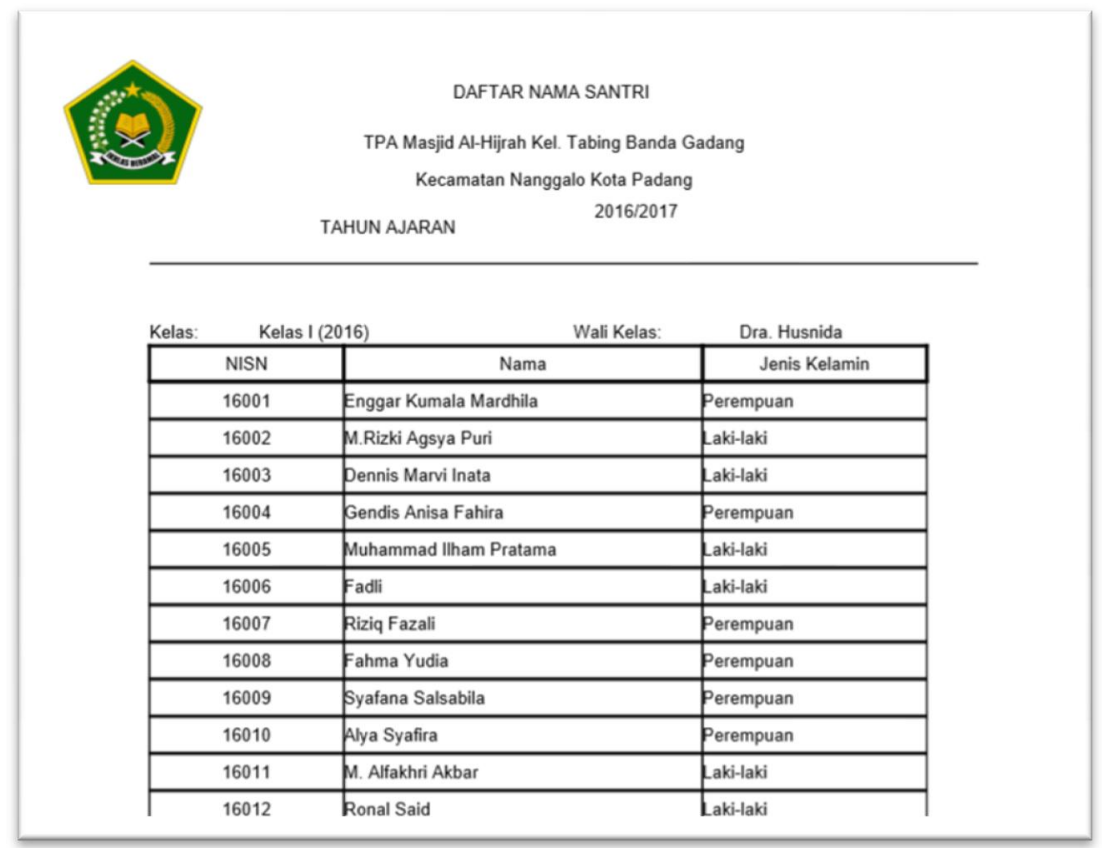

Gambar 5. Tampilan Rekapitulasi Data Santri

Gambar 6 berikut merupakan tampilan jadwal kegiatan yang bisa diunduh berdasarkan kelas. Jadwal ini bisa diunduh oleh ketiga user. 


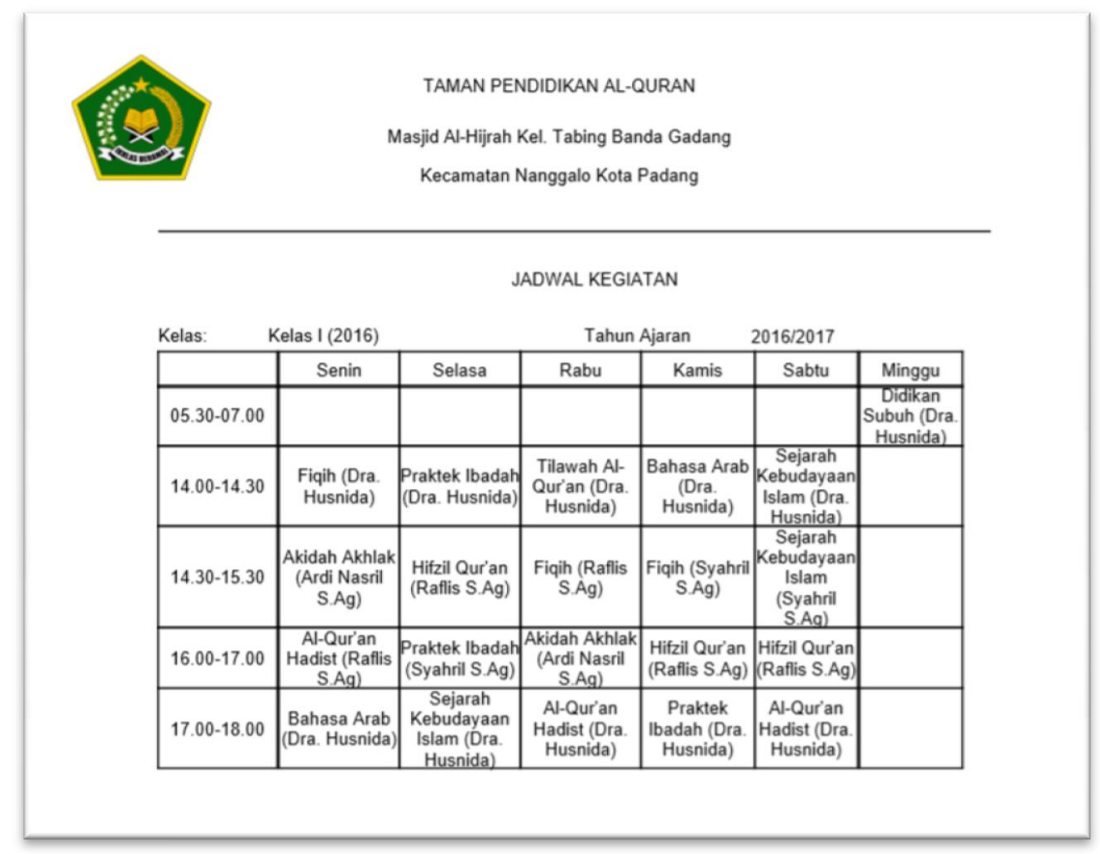

Gambar 6. Tampilan Rekapitulasi Jadwal Kegiatan

Khusus untuk halaman administrator dan guru, terdapat halaman rekapitulasi kehadiran seperti terlihat pada Gambar 7. Dengan adanya rekapitulasi kehadiran, akan memudahkan user untuk mengetahui santri yang tidak hadir.

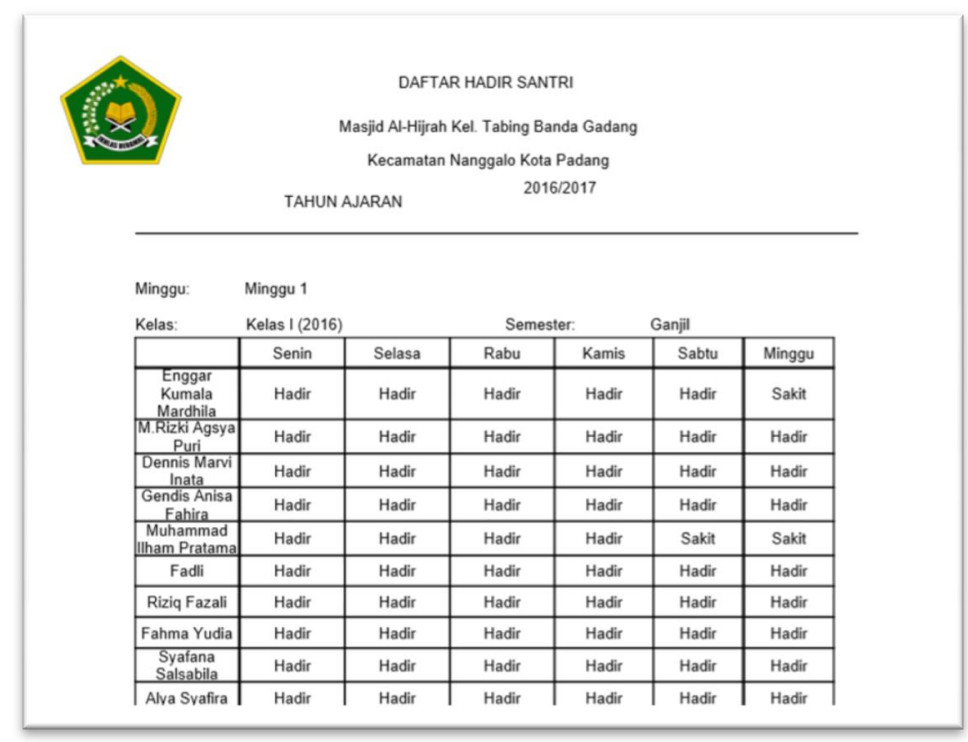

Gambar 7. Rekapitulasi Kehadiran

Sementara untuk user santri, hanya bisa mengunduh rekapitulasi kehadiran untuk dirinya sendiri seperti pada Gambar 8 berikut. 


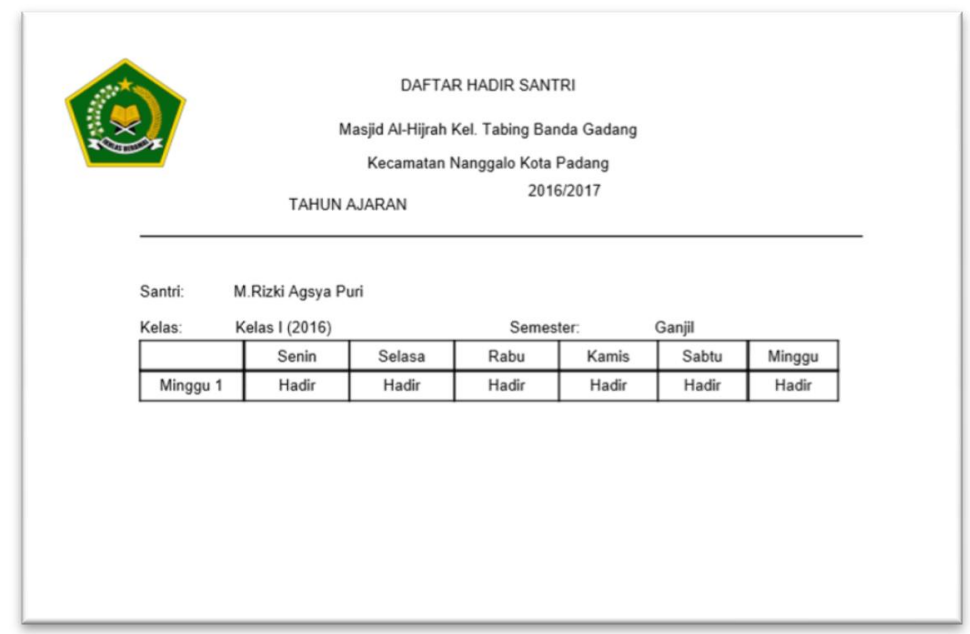

Gambar 8. Tampilan Report Kehadiran untuk User Santri

Gambar 9 berikut merupakan tampilan nilai rapor semester berdasarkan tingkatan kelas dan semester yang dipilih yang dapat dicetak oleh masing-masing santri.

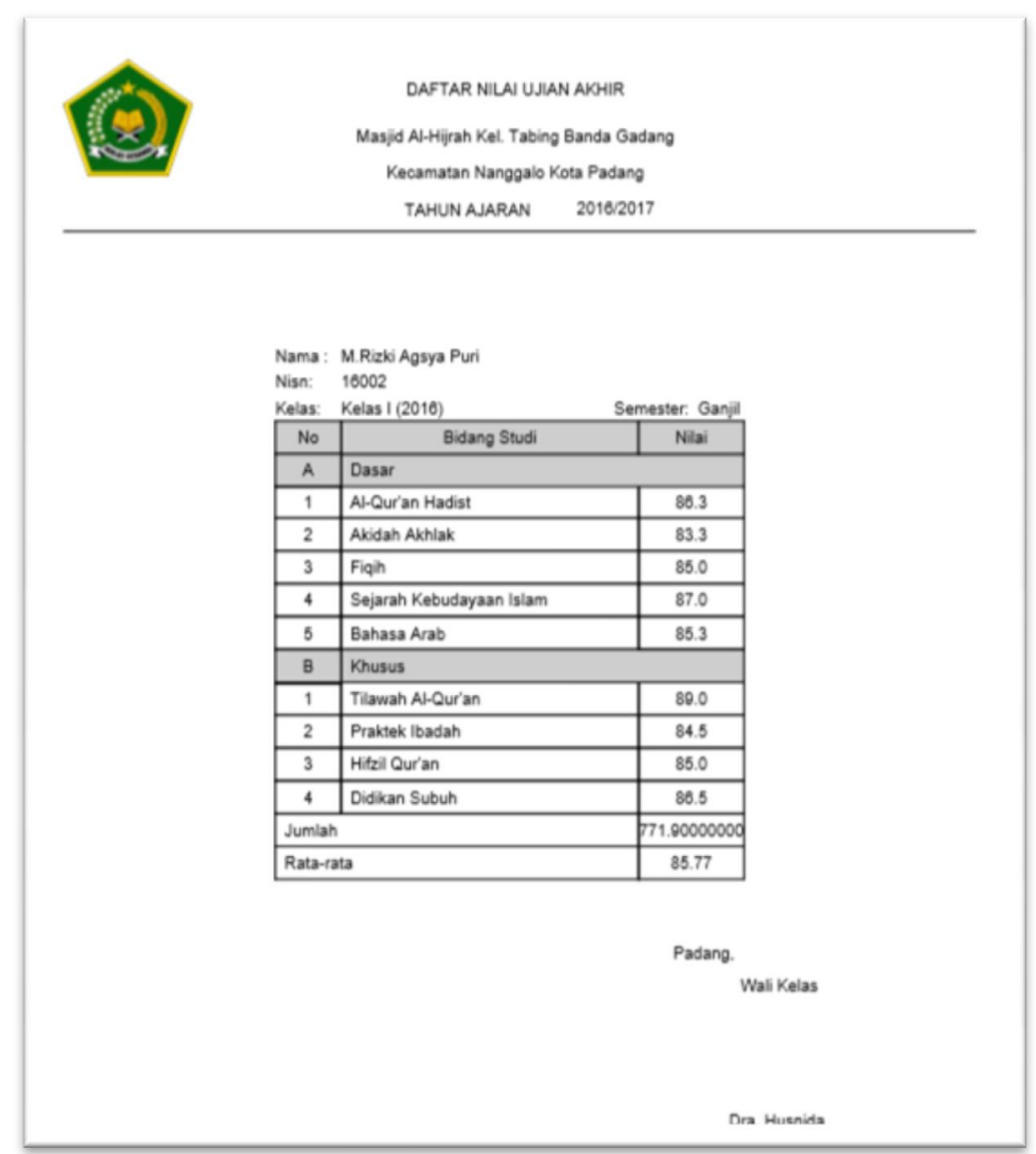

Gambar 9. Tampilan Rapor Nilai Semester 


\section{KESIMPULAN DAN SARAN}

Pengembangan Sistem Informasi TPA ini sudah berhasil dilakukan dengan menggunakan beberapa langkah dalam metodologi System Development Life Cycle (SDLC). Sistem ini sudah diujikan menggunakan data yang terdapat pada TPA Al Hijrah Kecamatan Nanggalo Kota Padang. Dalam pengembangan system digunakan bahasa pemrograman Java dengan framework Spring $M V C$ yang menyediakan fitur pengembangan web yang memisahkan proses bisnis pada user interface (client layer), server layer dan data access layer. Setelah dilakukan pengujian terbukti bahwa sistem sudah dapat mengatasi permasalahan validitas dari rekapitulasi data pada TPA tersebut dengan menyajikan informasi mengenai data santri, guru, rekapitulasi jadwal kegiatan, rekapitulasi kehadiran dan penilaian hasil setiap siswa. Untuk penelitian yang akan datang, diharapkan system bisa dikembangkan lagi dan diintegrasikan dengan system informasi yang lainnya.

\section{DAFTAR PUSTAKA}

[1] Pandunata, P., 2019, "Penataan Administrasi Data Siswa Taman Pendidikan Al-Qur'an An-Nida Menggunakan Teknologi Informasi dan Komunikasi”, JPP IPTEK Vol. 3, No. 1.

[2] Diah, R., 2015, "Rancang Bangun Website dan E-Learning di TPQ Al-Fadhillah", Program Studi Informatika Fakultas Informasi dan Informatika. Universitas Muhammadiyah, Surakarta.

[3] Setiawan, A., Hauzan, N.A.F., 2019, "Aplikasi Pengelolaan Data Akademik Berbasis Web pada Badan Koordinasi Taman Pendidikan Al-Quran”, Jurnal Sistem Informasi Vol. 6 No. 1.

[4] A.-B. bin Ladjamudin, 2005, "Analisis dan Desain Sistem Informasi," Graha Ilmu, Yogyakarta.

[5] Whitten, Bentley, 2011, "System Analysis \& Design Methods Seventh Edition", Mc Graw Hill. New York.

[6] Joshi, R., “Java Design Patterns0: Reusable Solutions to Common Problems”, Java Code Geek Java 2 Java Developers Resource Center.

[7] Goodrich, MT., Tamassia, R., 2010, "Data Structures \& Algorithms in Java Fourth Edition, John Wiley \& Sons.

[8] Rastogi,V., 2015, Software Development Life Cycle Models - Comparison, Consequences", International Journal of Computer Science and Information Technologies Vol. 6 No. 1, pp 168-172.

[9] Pressman, R., 2010. "Software Engineering A Practitioner's Approach Seventh Edition", Mc Graw Hill.

[10] Tjiptabudi, F., 2017, “Analisis dan Perancangan E-Business Berbasis Website Menggunakan PIECES Framework”, Jurnal HOAQ - Teknologi Informasi Vol. 8, No. 1. 